\title{
Floral morphology and HPTLC fingerprint profile of Saraca asoca (Roxb.) De Wilde (Caesalpiniaceae): A consecrated tree of India
}

\author{
Shanti Bhushan Mishra ${ }^{1 *}$ M. Vijayakumar ${ }^{2}$ \\ ${ }^{1}$ Department of Pharmacognosy, United Institute of Pharmacy, Naini, Allahabad, India \\ ${ }^{2}$ Research \& Development division, The Himalaya Drug Company, Makali, Bangalore, India \\ *E-mail address: shantipharma15@gmail.com
}

Keywords: Flower, HPTLC, Pharmacognostical, Phytochemical, Plant extract, Saraca asoca

\begin{abstract}
Pharmacognosy of the flowers of Saraca asoca (Roxb.) De Wilde has been carried out to lay down standards for the genuine drug Ashoka with the detailed anatomy of various floral appendages. The aim of the present study is to determine the physico-chemical profile, preliminary phytochemical screening, fluorescence analysis and chemical composition by HPTLC of the medicinally important plant Saraca asoca. These observations would be of immense value in the botanical identification and standardization of the drug in crude form. This study would help distinguish the drug from its other species.
\end{abstract}

\section{INTRODUCTION}

The significance of pharmacognosy has been extensively believed in modern epoch. Taxonomic classification, identification, pharmacognostic study includes the quality parameters which help in identifying the adulteration of crude drugs even in dry powder form also. This is again necessary because once the plant is dried and made into powder form, it loses its morphological identity and easily prone to adulteration. Pharmacognostic studies make sure plant identity, lays down standardization parameters which will help and prevents adulterations. [1]

Saraca is a small genus of shrubs or trees distributed in continental South-East Asia from India to South-West China. It occurs almost throughout India up to an altitude of $750 \mathrm{~m}$ in the central and the eastern Himalayas and the Khasi, Garo \& Lushai hills. [2] S. asoca is legendary and sacred tree of India having one of the most fascinating flowers in the Indian range of flower essences. According to traditional literature, the flowers are considered to be uterine tonic and are used in vitiated conditions of pitta, syphilis, cervical adenitis, hyperdipsia, burning sensation, haemorrhoids, dysentery, scabies in children and inflammation. The dried flowers are used in diabetes and haemorrhagic dysentery and seeds are used for treating bone fractures, stangury and vesical calculi. [3] Scientifically the plant is to be proven as Antibacterial, Antimicrobial, [4], Anthelmintic, [5] Analgesic, [6] Antihyperglycemic / Antioxidant, [7, 8] CNS Depressant Activity, [9] Anti-Arthritic / Anti-Inflammatory, [10] Cytotoxicity, [11] Anti-Platelet Aggregation, [12] AntiDiarrheal, [13] Larvicidal [14], antifungal [15]. Chemically it contain Labdane Diterpene, 6,9epoxy marrubiinic acid, steroids, Flavonoids, lignin glycosides, Gallic acid, [16,17] The present investigation deals with the study of pharmacognostical characteristics of the flowers and phytochemical analysis by high performance thin layer chromatography. 


\section{MATERIALS}

\section{Plant material}

The fresh flowers of plant Saraca asoca was collected from National Botanical Research Institute campus, Lucknow in the month of March and authenticated by Dr. A. K. S. Rawat with voucher specimen number CIFRB-2-126-3 deposited in the departmental herbarium of National Botanical Research Institute Lucknow, India for future reference.

\section{Chemicals and Instruments}

All the chemicals and reagents like chloral hydrate, phloroglucinol, Ethanol, Methanol, lead acetate, hydrochloric acid, potassium hydroxide, picric acid, and nitric acid etc., used were of analytical and highest purity grade from standard companies. Water represents the double distilled water. Sisco muffle furnace, Stage micrometer and eye piece micrometer, HPTLC plates (Merck), HPTLC (WinCats software, CAMAG, Switzerland).

\section{METHODS}

\section{Morphological and anatomical analysis}

The morphological characteristics of the plant were studied with the help of literature available in Kirtikar and Basu [18]. All the drawing of floral diagram and floral formula has been done with the help of camera lucida and microscope. All floral characters were compared with the literature available on the plant. $[19,20]$

\section{Determination of physicochemical parameters}

The Moisture content, ash values, extractive values with various reagents and were determined as per the Indian Pharmacopoeia.[21] The fluorescence characters of the flower powder with various reagents were observed under visible light and UV light (254 \& $366 \mathrm{~nm})$ as per the standard procedure.[22-23]

\section{PRELIMINARY PHYTOCHEMICAL SCREENING}

\section{Preparation of extract}

The freshly collected flowers $(2 \mathrm{~kg})$ of $\mathrm{S}$. asoca were first air-dried and then dried in tray drier under control conditions and powdered. The powdered flowers $(950 \mathrm{~g})$ were macerated with petroleum ether to remove fatty substances; the marc was further exhaustively extracted with of $50 \%$ ethanol for 3 days ( 3 X 3L) by cold percolation method and centrifugation at $10,000 \mathrm{rev} / \mathrm{min}$. The extract was separated by filtration and concentrated on rotavapour (Buchi, USA) and then dried in lyophilizer (Labconco, USA) under reduced pressure and thus $100.0 \mathrm{~g}$ of solid residue (yield $10 \% \mathrm{w} / \mathrm{w}$ ) was obtained. The extract was subjected to preliminary phytochemical screening for the identification of various phytoconstituents present in the extract [24, 25].

\section{HPTLC finger print profile}

High performance thin layer chromatography (HPTLC) can successfully be employed for finger printing of S. asoca. Pre-coated silica gel 60 F254 plate (E. Merck) of uniform thickness $0.2 \mathrm{~mm}$ was used for the HPTLC analysis. Samples were applied in the form of bands using Linomat IV applicator of CAMAG for HPTLC analysis. The plates were eluted in ethyl acetate: acetic acid: formic acid: methanol $(7.5: 1: 0.5: 1)$ as mobile phase in CAMAG twin trough chambers. The chambers were saturated with the respective mobile phases for a period of 30 minutes before the 
elution. Video documentation of the eluted plates was carried out using Desaga Video documentation unit. Eluted plates were then densitometrically scanned using CAMAG scanner 3 at $254 \mathrm{~nm}$ wavelength. HPTLC was performed both qualitatively and quantitatively for flower extract.

\section{RESULTS AND DISCUSSION}

\section{Pharmacognostical Study}

\section{Morphological analysis}

A tree about 6-9 m. high, branches glabrous. Leaves paripinnate, 15-20 cm long, leaflets 6-12, oblong or oblong lanceolate, corky at the base, petioles very short, stipules intrapetiolar, completely united. Flowers are usually to be seen throughout the year, but it is in January to March that the profusion of orange and scarlet clusters turns the tree into an object of startling beauty. Pinned closely on to every branch and twig, these clusters consist of numerous, small, long-tubed flowers which open out into four oval lobes. Yellow when young, they become orange then crimson with age and from the effect of the sun's rays eventually turning vermillion. From a ring at the top of each tube spread several long, half-white, half-crimson, stamens which give a hairy appearance to the flower clusters. Pods black, flat, leathery, $10-25 \mathrm{~cm}$ x $3.5-5 \mathrm{~cm}$, seeds $4-8$, ellipsoid-oblong, 28 cm. compressed.

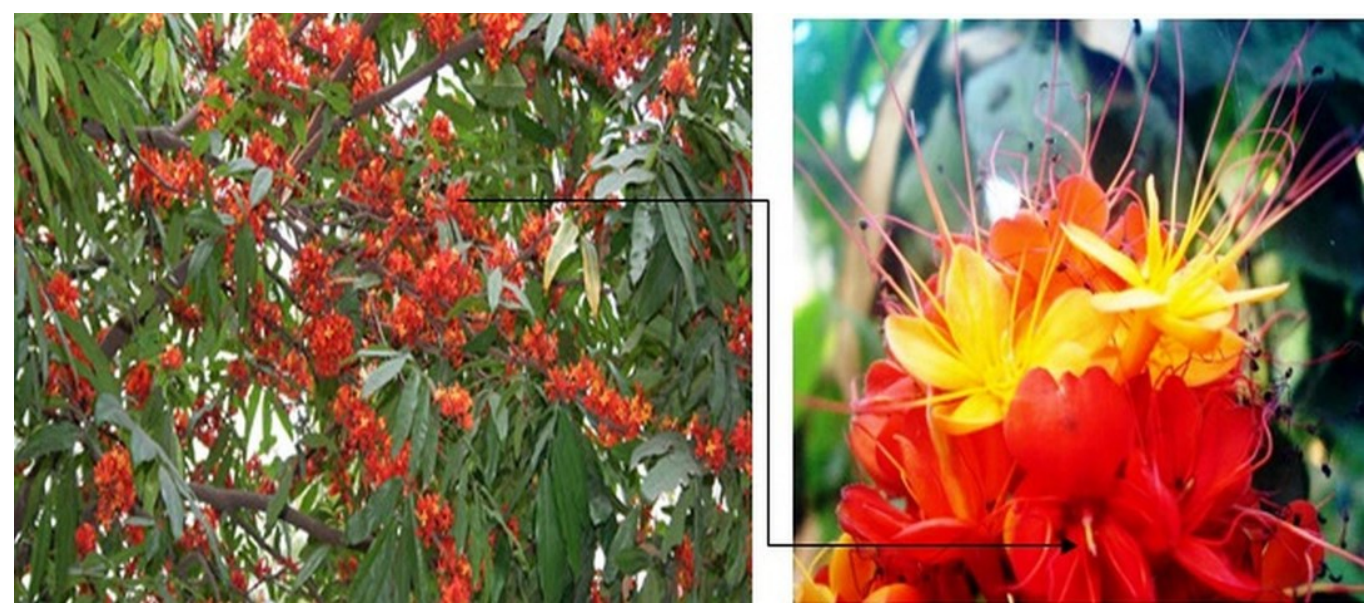

Fig. 1, Flowers of Saraca asoca

\section{Anatomical and diagnostic characters}

The flowers of many legumes, particularly those in subfamily Caesalpinioideae, show loss of some organs. The flowers of Saraca are not typical of Caesalpiniaceae. They differ from the other members of this alliance in the complete absence of petals. The yellow to rose, red orange, or red flowers are arranged in compact sessile or short-stalked paniculate lateral corymbs with three orders of branching. Bracts and pairs of small colored bracteoles subtend each flower, but they are shorter than the hypanthium and do not cover the flower. The bracteoles endure for a short time. The salient features of Saraca flowers are the colorful bracteoles; the spreading petaloid tetramerous imbricate calyx in orange, yellow, or red; the lack of a corolla; and the four to seven (with a range of 3-10) free long-filamentous orange stamens, some of which may be either missing or modified as staminodia. Saraca asoca most often has seven stamens. The gynoecium is longstipitate, sigmoid in shape, and adnate to one side of the hypanthium. There are a coiled filiform style in bud, an obtuse stigma, and numerous ovules. The disk is orange initially, and later it darkens to purple in both species. Fusion of the two adaxial sepal primordia to form a single structure, which results in a tetramerous calyx. Of the seven stamens in $S$. asoca, the three most abaxial primordia (two of the outer whorl and one of the inner whorl) are initially slightly larger than the others. (Figure 2) 

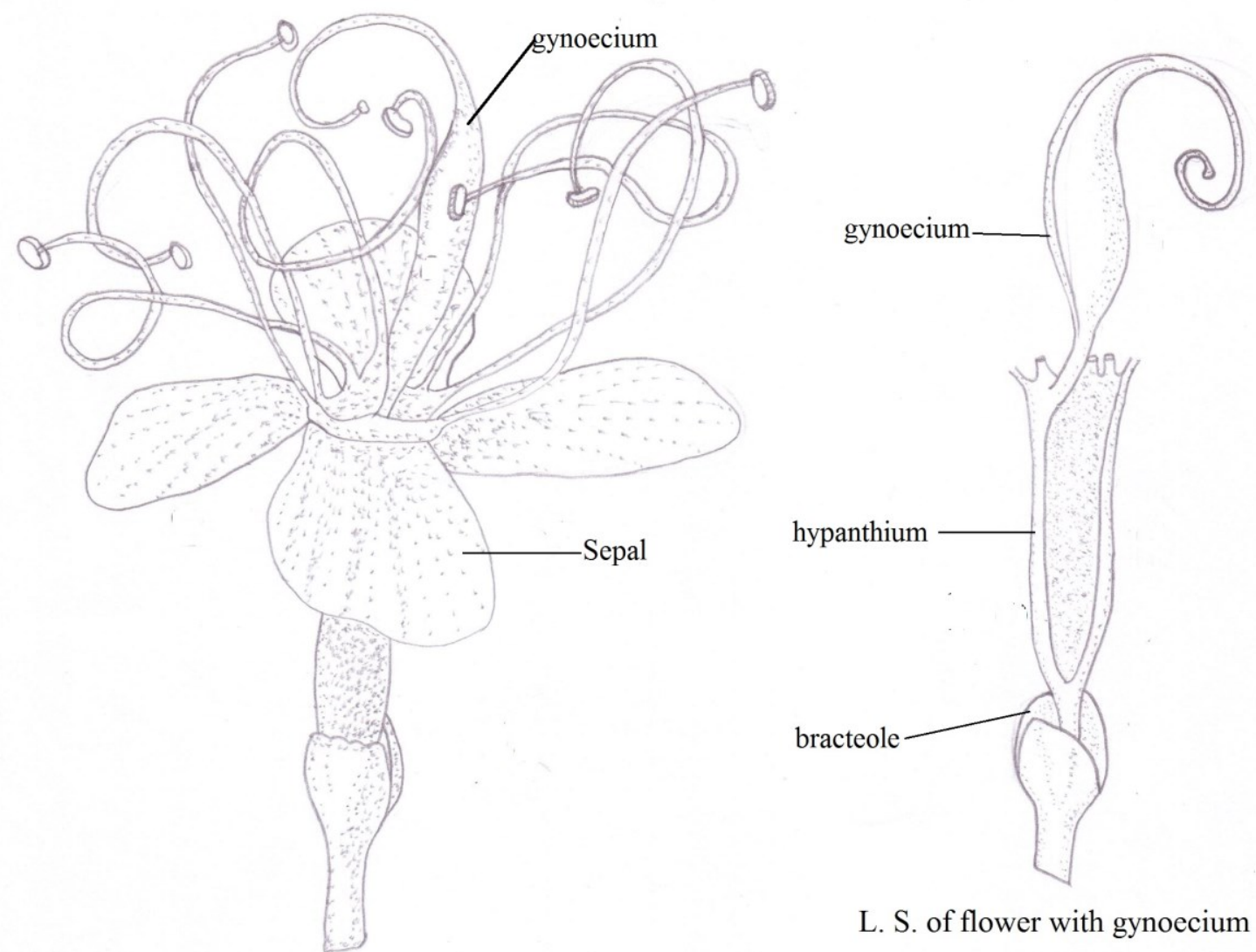

L. S. of flower with gynoecium

Sketch of flower
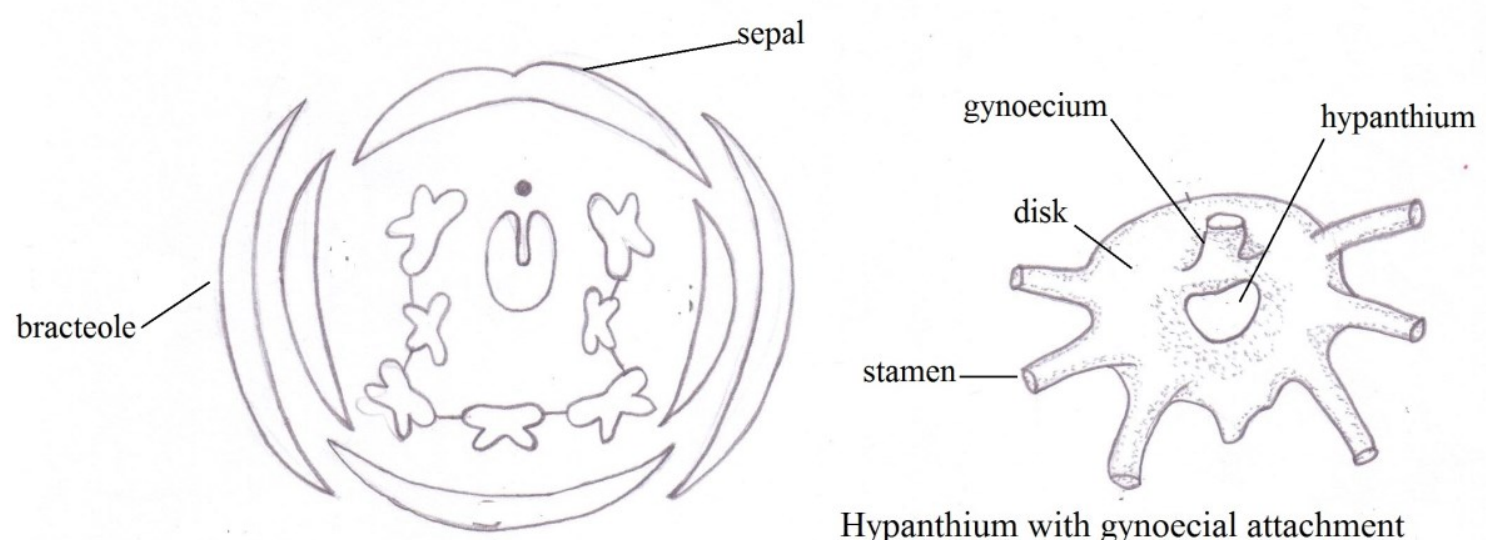

Hypanthium with gynoecial attachment

Floral diagram bract

Fig. 2, Camera Lucida drawings and floral diagram of Saraca asoca 


\section{Physico-chemical parameters}

The ash remaining following ignition of medicinal plant material is determined by estimating total ash, acid-insoluble ash and water soluble ash. The method is designed to measure the total amount of material remaining after ignition. This includes both 'physiological ash' which is derived from plant tissue itself, and 'non-physiological ash' which is the residue of the extraneous matter (e.g. sand and soil) adhering to the plant surface. Acid -insoluble ash is the residue obtained after boiling the total ash with dilute hydrochloric acid and igniting the remaining the insoluble matter. [26] This measure the amount of silica present, especially as sand and siliceous earth that may be added on at the time of collection. Water-soluble ash is the difference in the weight between the total ash and the residue after the treatment of the total ash with water. Different physicochemical parameters of the selected plants are given in Table no. 1

\begin{tabular}{ll} 
Table 1, Physico-chemical parameters of Saraca asoca \\
\cline { 1 - 2 } Parameter & $\mathbf{\% ~ w / \mathbf { w } ^ { * }}$ \\
\hline Foreign matter & 0.9 \\
Moisture content & 0.05 \\
Total ash & 5.66 \\
Water soluble ash & 3.0 \\
Acid insoluble ash & 3.33 \\
Alcohol soluble extractive value & 17.2 \\
Water soluble extractive value & 13.4 \\
\hline
\end{tabular}

\section{Fluorescence analysis}

Many substances for example, quinine solution in dilute sulphuric acid when suitably illuminated emit light of a different wavelength or color from that which falls on them. This emitted light (fluorescence) ceases when the exciting light is removed. A very important generalization made by stokes in 1852 stated that 'in fluorescence the fluorescent light is always of greater wavelength than the exciting light'. Light rich in short wavelengths is very active in producing fluorescence and for this reason strong ultraviolet light produces fluorescence in many substances which do not visibly fluoresce in day light. [27] Fluorescence Analysis of powder results are given in table no 2

*Average of three readings

Table 2, Fluorescence analysis of Saraca asoca powder

\begin{tabular}{llll}
\hline S.No. & Reagents & \multicolumn{2}{l}{ Color of the powdered drug } \\
\cline { 3 - 4 } & & Day light & Ultraviolet light (254nm) \\
1. & Saturated picric acid & Reddish brown & Greenish \\
2. & $50 \%$ Nitric acid & yellowish & Greenish \\
3. & Hydrochloric acid & Red & Black \\
4. & Sulphuric acid $(80 \%)$ & Black & Black \\
5. & Glacial acetic acid & Reddish brown & Brown \\
6. & Iodine solution $(\mathrm{N} / 20)$ & Black & Dark green \\
7. & Powder as such & Brownish & Dull brown \\
8. & Methanol & Violet & Violet \\
\hline
\end{tabular}




\section{Preliminary Phytochemical study}

The phytoconstituents were identified by chemical tests, which showed the presence of various secondary metabolites like saponns, fixed oil and fats, phenolic compounds, Phytosterols and flavonoids in 50\% ethenolic extract of $S$. asoca depicted in table no. 3

Table 3, Preliminary phytochemical screening of the $50 \%$ ethanolic extract of $S$. asoca

\begin{tabular}{|c|c|c|c|}
\hline S. No. & Constituents & Tests & $\begin{array}{l}50 \% \text { Ethanolic } \\
\text { extract }\end{array}$ \\
\hline \multirow[t]{2}{*}{1.} & Carbohydrate & Molish's test & - \\
\hline & & Fehling's test & - \\
\hline \multirow[t]{2}{*}{2.} & Fixed oil \& fats & Spot test & + \\
\hline & & Saponification test & + \\
\hline \multirow[t]{3}{*}{3.} & Proteins \& amino acids & Million's test & - \\
\hline & & Ninhydrin test & - \\
\hline & & Biuret test & - \\
\hline 4. & Saponins & Foam test & + \\
\hline \multirow[t]{3}{*}{5.} & Phenolic compounds & $\mathrm{FeCl}_{3}$ test & + \\
\hline & & Pot. permagnate test & - \\
\hline & & Lead acetate test & - \\
\hline \multirow[t]{2}{*}{6.} & Phytosterol & Salkowiski test & + \\
\hline & & $\begin{array}{l}\text { Libermann burchard } \\
\text { test }\end{array}$ & + \\
\hline \multirow[t]{4}{*}{7.} & Alkaloids & Dragendroff's test & - \\
\hline & & Mayer's test & - \\
\hline & & Wagner's test & - \\
\hline & & Hager's test & - \\
\hline 8. & Gum \& mucilage & Swelling test & - \\
\hline \multirow[t]{3}{*}{9.} & Flavonoids & Aqueous $\mathrm{NaOH}$ test & + \\
\hline & & Con. $\mathrm{H}_{2} \mathrm{SO}_{4}$ test & + \\
\hline & & Shinoda's test & + \\
\hline
\end{tabular}

\section{HPTLC Fingerprinting Profile}

HPTLC is a versatile separation technique, which is official in most of the Pharmacopoeia intended for determining the content uniformity, purity, assay value, dissolution, drug-drug interaction and bioavailability of the drugs. It is precisely for these reasons that almost every research laboratory today is equipped with HPTLC system. [28] It simultaneously handles a number of samples even of divergent nature and composition supporting several analyses at a given time. It can be considered a time machine that can speed the work usually impractical with other analytical techniques.

$10 \mathrm{mg}$ of $50 \%$ ethanolic extract was dissolved in $1.0 \mathrm{ml}$ of $80 \%$ aqueous methanol and used for HPTLC analysis. $10 \mu \mathrm{l}$ of the test solution was applied and the plates were then developed in ethyl acetate: acetic acid: formic acid: methanol (7.5:1:0.5:1) to a distance of $9 \mathrm{~cm}$. Developed plate was then observed under visible light after derivatization with anisaldehyde sulphuric acid reagent and scanned densitometrically at $254 \mathrm{~nm}$ which showed the presence of nine spots at $\mathrm{R}_{\mathrm{f}}$ of $0.04,0.10$, $0.15,0.23,0.52,0.58,0.70,0.78$ and 0.92 . (Figure 3 ) 


\section{UV 254nm}
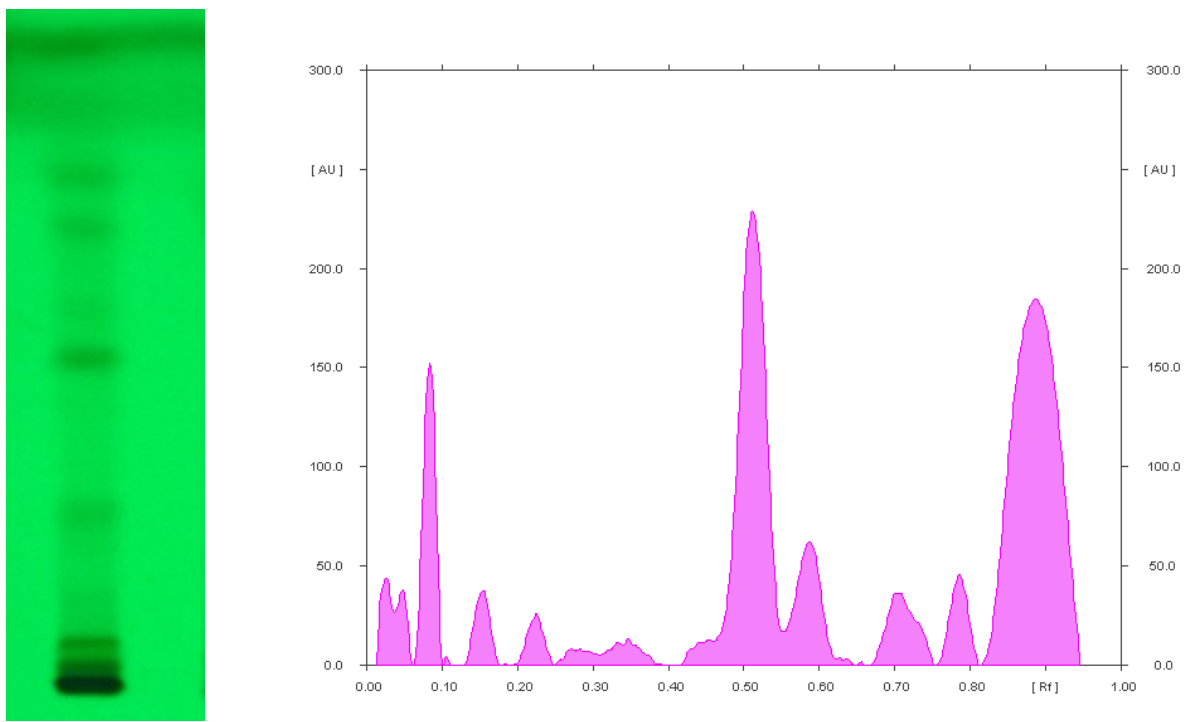

Fig. 3, HPTLC fingerprint profile of $S$. asoca extract at $254 \mathrm{~nm}$

\section{CONCLUSION}

Plant based crude drugs whose botanical identity is not known are identified based on their morphological and anatomical characters. Pharmacognosy is closely related to botany and plant chemistry and, indeed, both originated from the earlier scientific studies on medicinal plants. In the present paper, the morphological and anatomical findings will help the future investigators for proper identification from other species of Saraca viz. S. declinata, while other parameters will provide additional information about this plant to prepare a monograph and standardization of the plant material in quality determination. It is apparent from this work that the flower part of the plant to be used as a drug since the extract contains various phytoconstituents at different concentration.

\section{Acknowledgement}

The authors sincerely thank to Prof. (Dr.) Alok Mukerjee, Principal United Institute of Pharmacy, Allahabad, for providing all the facilities to carry out the experimental studies.

\section{References}

[1] S. Chanda, Importance of pharmacognostic study of medicinal plants: An overview, J. Pharmacog. Phytochem. 2 (2014) 69-73.

[2] K.R. Kirtikar, B.D. Basu, Indian medicinal plants, second ed., Vol. II, Int. book distributors, Dehradun, India, 2006.

[3] Wealth of India. Raw Materials, Vol IX, A Dictionary of Indian raw materials and industrial products, 2009.

[4] R.S. Sainath, J. Prathiba, R. Malathi, Antimicrobial properties of the stem bark of Saraca indica (Caesalpiniaceae), Eur. Rev. Med. Pharmacol. Sci. 13 (2009) 371-374.

[5] A. Sharma, S. Gupta, S. Sachan, A. Mishra, A. Banarji, Anthelmintic activity of the leaf of Saraca indica Linn, Asian J. Pharm. Life Sci. 1 (2011) 391-395.

[6] A. Verma, G.K. Jana, R. Chakraborty, S. Sen, S. Sachan, A. Mishra, Analgesic activity of various leaf extracts of Saraca indica Linn, Der. Pharmacia. Lettre. 2 (2010) 352-357. 
[7] S. Kumar, S. Narwal, D. Kumar, G. Singh, S. Narwal, R. Arya, Evaluation of antihyperglycemic and antioxidant activities of Saraca asoca (Roxb.) De Wild leaves in streptozotocin induced diabetic mice, Asian Pac. J. Trop. Disease. 2 (2012) 170-176.

[8] S.B. Mishra, M. Vijayakumar, Anti-hyperglycemic and antioxidant effect of Saraca asoca (Roxb. De Wilde) flowers in Streptozotocin-Nicotinamide induced diabetic rats: A therapeutic study, J. Bioanal. Biomed. (2014) S12: 003.

[9] A. Verma, K.J. Goutam, S. Sen, R. Chakraborty, S. Sachan, A. Mishra, Pharmacological evaluation of Saraca indica leaves for central nervous system depressant activity in mice, J. Pharm. Sci. \& Res. 2 (2010) 338-343.

[10] M. Gupta, S. Sasmal, A. Mukherjee, Therapeutic effects of acetone extract of Saraca asoca seeds on rats with adjuvant-induced arthritis via attenuating inflammatory responses, ISRN Rheumatology, vol. 2014, Article ID 959687, 12 pages, (2014), doi:10.1155/2014/959687

[11] A. Asokan, M. Thangavel, In vitro cytotoxic studies of crude methanolic extract of Saraca indica bark extract, IOSR J. Pharm. Biol. Sci. 9 (2014) 26-30.

[12] S. Kalakotla, K.M. Gottumukkala, M. Sandhya rani, P.L. Pravallika, Phytochemical screening and in-vitro anti-platelet aggregation activity of Saraca indica Linn, Indo Am. J. Pharm. Res. 4 (2014) 2730-2735.

[13] S. Panchawat, S.S. Sisodia, In-vivo antidiarrhoeal activity of extracts from stem bark of Saraca asoca Roxb. prepared by different extraction methods, IJPBS 2 (2012) 338-343.

[14] N. Mathew, M.G. Anitha, T.S.L. Bala, S.M. Sivakumar, R. Narmadha, M. Kalyanasundaram, Larvicidal activity of Saraca indica, Nyctanthes arbor-tristis, and Clitoria ternatea extracts against three mosquito vector species, Parasitology Res. 104 (2008) 1017-1025.

[15] U. Hawas, S. Eltomy, R. Nassif, G. El-Hossary, S. AbouZid, A new antifungal labdane diterpene from the leaves of Saraca indica, Nat. Prod. Res. (2013) 1-6 doi.10.1080/14786419.2013.855931

[16] S.K. Sadhu, A. Khatoon, P. Phattanawasin, O. Takashi, I. Masami, Lignan glycoside and flavonoids from Saraca asoca with antioxidant activity, J. Nat. Med. 61 (2007) 480-482.

[17] J. Saha, T. Mitra, K. Gupta, Phytoconstituents and HPTLC analysis in Saraca asoca (Roxb) Wilde, Int. J. Pharm. Pharm. Sci. 4 (2012) 96-99.

[18] K.R. Kirtikar, B.D. Basu, Indian medicinal plants, II ed., Vol.II, Published by Int. book distributors, Dehradun, India 2006, pp-883-884.

[19] M.M. Hartog, On the floral organogeny and anatomy of Brownea and Saraca, Ann. Bot. 2 (1888) 309-318.

[20] E.R. Saunders, The cause of petaloid colouring in apetalous fiowers, J. Linn. Soc. Bot. 49 (1933) 199-218.

[21] Indian pharmacopoeia, Vol. I, 6th ed., Govt. of India, Ministry of health \& family welfare published by the Indian pharmacopoeia commission Ghaziabad, 2010, p. 82-83

[22] C.R. Chase, R.J. Pratt, Fluorescence of powdered vegetable drugs with particular reference to development a system of identification, J. Am. Pharmacol. Assoc. 38 (1949) 324-331.

[23] C.J. Kokoski, R.J. Kokoski, F.J. Salma, Fluorescence of powdered vegetable drugs under ultraviolet radiation, J. Am. Pharmacol. Assoc. 47 (1958) 715-717.

[24] J.B. Harborne, Method of extraction and isolation In. Phytochemical Methods, Chapman \& Hall, London, 1998. 
[25] C.K. Kokate, A.P. Purohit, S.B. Gokhale, Pharmacognosy, twentieth ed. Nirali Prakashan, Pune, 2002.

[26] S.B. Mishra, A. Mukerjee, M. Vijayakumar, Pharmacognostical and phytochemical evaluation of leaves extract of Jatropha curcas Linn, PhCog. J. 2 (2010) 9-15.

[27] S.B. Mishra, M. Vijayakumar, Phytochemical analysis and histology of Strychnos potatorum L. Seeds, Hygeia. J. D. Med. 6 (2014) 17-24.

[28] S.B. Mishra, A. Verma, A. Mukerjee, M. Vijayakumar, Pharmacognostic standardization and phytochemical screening of leaves of Amaranthus spinosus L, PhCog. J. 3 (2011) 34-38. 